\section{The HIV-1 Tat cellular coactivator Tat-SF1 is a general transcription elongation factor}

\author{
Xiao-Yong Li and Michael R Green ${ }^{1}$ \\ Howard Hughes Medical Institute, Program in Molecular \\ Medicine, University of M assachusetts M edical Center, \\ Worcester, M assachusetts 01605 USA
}

\begin{abstract}
The human immunodeficiency virus type 1 (HIV-1) Tat protein strongly and specifically stimulates transcription elongation from the HIV-1 LTR and provides an important in vitro model system to study this process. Herewe use protein-affinity chromatography to identify cellular factors involved in transcription elongation. A Tat-affinity column bound one transcription factor, Tat-SF1, efficiently and selectively. Tat-SF1 was identified originally as a Tat-specific coactivator, but we show it is a general transcription elongation factor. Our results also reveal the existence of an ATP-inactivatable general elongation factor (AIEF) required for Tat-SF1 activity and for which Tat can substitute functionally.
\end{abstract}

Received July 14, 1998; revised version accepted August 18, 1998.

Transcription in eukaryotic cells requires the assembly of an elaborate multisubunit preinitiation complex, followed by initiation, elongation, and termination. Although it was thought originally that regulation occurs primarily at the level of initiation, it is now recognized that some genes are regulated, at least in part, at the transcription el ongation step (for review, see Bentley 1995). Recent studies suggest that regulation of elongation is probably of general importance in eukaryotic gene expression, especially in higher organisms (for review, see Bentley 1995; Li and Green 1996a). Compared to our understanding of transcription initiation, much less is known about the factors and mechanisms involved in transcription el ongation.

The human immunodeficiency virus-1 (HIV-1) Tat protein is a potent activator of the HIV-1 long terminal repeat (LTR) and functions by binding to an RNA element, Tar, in the nascent transcript (for review, see Cullen 1993; Jones and Peterlin 1994). Tat can also stimulate transcription when directed to the promoter through a heterol ogous DN A-binding domain (Southgate and Green 1991), suggesting that it may be functionally similar to typical activators that target promoters by sequence-specific DN A binding. Based on both in vivo and in vitro evidence, HIV-1 Tat stimulates transcription at the level of elongation (Kao et al . 1987; Laspia et al. 1989;

[Key Words: HIV-1; Tat; Tat-SF1; transcription; el ongation factor] ${ }^{1}$ Corresponding author.

E-MAIL Michael.Green@ummed.edu; FAX (508) 856-5473.
Marciniak et al. 1990; Feinberg et al. 1991; Marciniak and Sharp 1991) and thus has provided a val uable system to study this process.

We investigate cellular factor(s) that are required for general and Tat-directed transcription elongation. Our results reveal a new general el ongation factor, Tat-SF1.

\section{Results and Discussion}

To identify cellular factors with which Tat interacts, a HeLa cell nuclear extract was chromatographed on a protein-affinity column containing immobilized wild-type Tat. A Tat activation-defective mutant, T at $(K 41 \mathrm{~A})$, was used as a control. Flowthrough (FT) fractions were tested initially in a standard run-off (RO) transcription assay using the generic DNA template, G5E1b. Figure $1 A$ shows that the crude nuclear extract and the T at mutant protein-affinity column FT supported efficient transcription elongation as evidenced by synthesis of an $\sim 1600$ nucleotide RO transcript. In contrast, the amount of 1600 nucleotide RO transcript synthesized in the FT of the wild-type Tat protein-affinity column was decreased dramatically. To determine whether the transcription defect was at the level of initiation or elongation, we performed primer-extension analysis using a 'promoterproximal' primer located near the transcription startsite. Figure $1 \mathrm{~A}$ shows that the FT fractions from the wild-type and mutant Tat columns, and the crude nuclear extract, all gave rise to a similar amount of this promoter-proximal primer-extension product. We conclude that the Tat-affinity column depleted a factor(s) involved specifically in transcription el ongation.

Figure $1 \mathrm{~B}$ shows that a $0.5 \mathrm{~m}$ el uate of the Tat proteinaffi nity column complemented the FT fraction, whereas the $1.0 \mathrm{~m}$ eluate had little effect. Primer-extension analysis reveal ed that the $0.5 \mathrm{~m}$ el uate had no si gnificant effect on transcription initiation. We conclude that the $0.5 \mathrm{~m}$ eluate of the Tat protein-affinity col umn contains a general transcription el ongation factor(s) that binds to the Tat-activation domain.

To determine whether the activity bound to the Tataffinity column corresponded to a known transcription component, we carried out immunoblot analysis using antibodies directed against various transcription-initiation factors [TFIIB, TFIID (TBP subunit), TFIIF (RAP30 subunit), TFIIH (ERCC3 subunit) (Drapkin et al. 1994)], el ongation factors [SII, Elongin (SIII) (Elongin B subunit) (Aso et al. 1995; Garrett et al. 1995), ELL (Shilatifard et al. 1996), P-TEFb (CDK9 subunit) (Zhu et al. 1997)], RN A polymerase II, and Tat-SF1 (Zhou and Sharp 1996), a putative Tat-specific cofactor. Figure 2 shows that of these factors, only Tat-SF1 was both depleted significantly from the Tat-affinity col umn FT and present at high concentration in the $0.5 \mathrm{~m}$ column el uate, which contained the elongation activity. The Tat-affinity column also bound several general transcription factors to a lesser extent, in particular, TFIIF and the cyclin-dependent kinase/P-TEFb subunit, CDK9, which have both been im- 


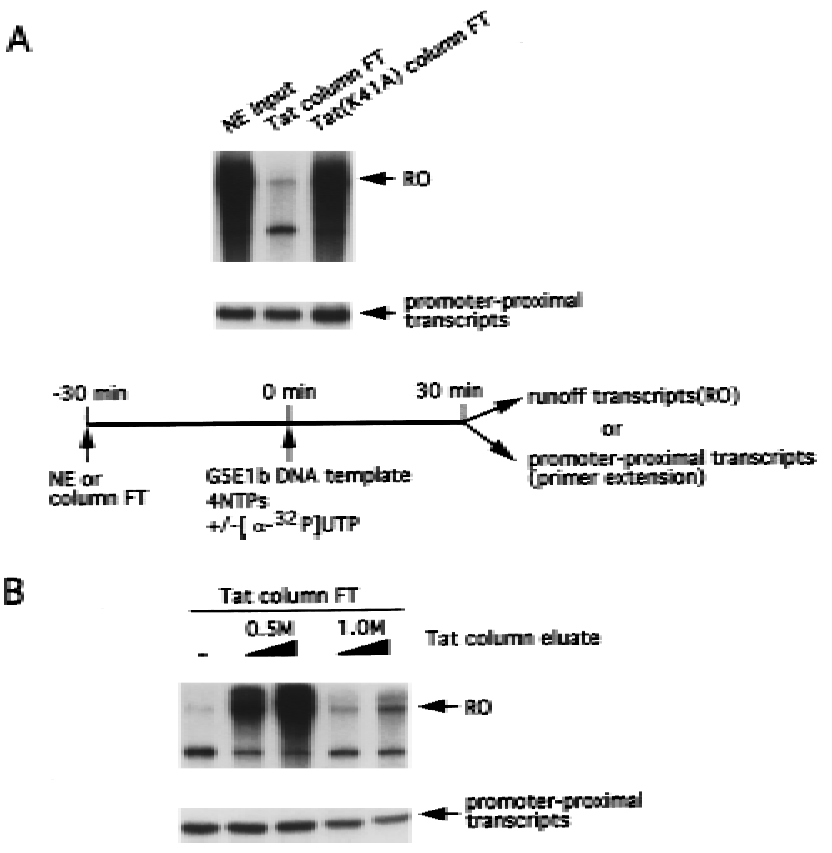

Figure 1. A T at-affinity column depletes a factor(s) required for transcription el ongation. N uclear extract was chromatographed on a Tat-affinity column, or a control column containing the Tat mutant, Tat (K41A). FT fractions were collected, and bound proteins eluted with $0.5 \mathrm{M}$ or $1.0 \mathrm{M} \mathrm{KCl}$. (A) Activities of the nuclear extract input and the FT fractions were tested in a standard RO transcription assay or by primer-extension. The RO transcripts are shown at top; the primer-extension products at bottom. (B) The Tat protein-affinity column eluates (5 or $10 \mu \mathrm{l}$ ) were tested for their ability to complement the Tat proteinaffinity column FT to support transcription. RO transcripts and primer-extension products are shown.

plicated in Tat function previously (Kato et al. 1992; Moncebo et al. 1997; Zhu et al. 1997; Gold et al. 1998; Wei et al. 1998).

To identify the general elongation factor retained on the Tat-affinity column, the $0.5 \mathrm{~m}$ column eluate was subjected to biochemical fractionation (see Materials and Methods). Figure 3A shows that the final fraction complemented the Tat-affinity column FT to support efficient el ongation. Significantly, the immunobl ot experiment of Figure 3B shows that this fraction contained high levels of Tat-SF1 but no other known transcription components. Because TFIIF was depleted modestly by the Tat-affinity column and has been implicated in transcription elongation previously (for review, see Bentley 1995; Reine et al. 1996), it was also tested. Figure 3A shows that TFIIF increased transcriptional activity of the Tat-affinity column FT (lane 2) and synergized with T atSF1 (lanes 3,4). However, whereas TFIIF stimulated production of all transcripts, Tat-SF1 appeared to stimulate exclusively production of full-length transcripts.

The finding that Tat-SF1 may be a general transcription elongation factor was unexpected because it was proposed originally to be a Tat-specific coactivator (Zhou and Sharp 1995, 1996). To confirm this conclusion, we

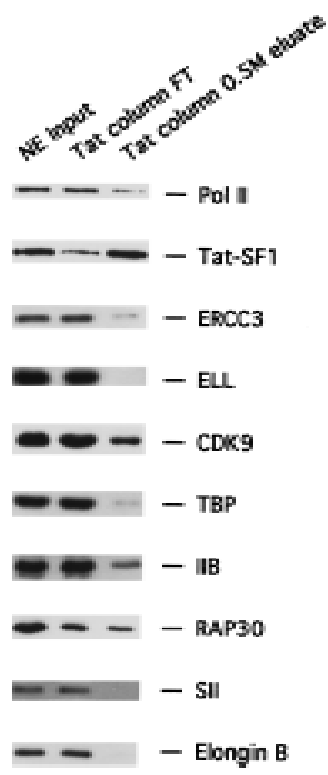

Figure 2. Selective depletion of Tat-SF1 by a Tat-affinity column. The presence of the known general transcription components in the nuclear extract input, Tat-affinity column flow through and the $0.5 \mathrm{~m}$ eluate was analyzed by immunobloting

expressed Tat-SF1 in a baculovirus system. Figure 3C shows that following addition to the Tat-affinity column flow through, the baculovirus-derived Tat-SF1 stimulated transcription elongation efficiently from three different DNA templates. Based on these results, we con-

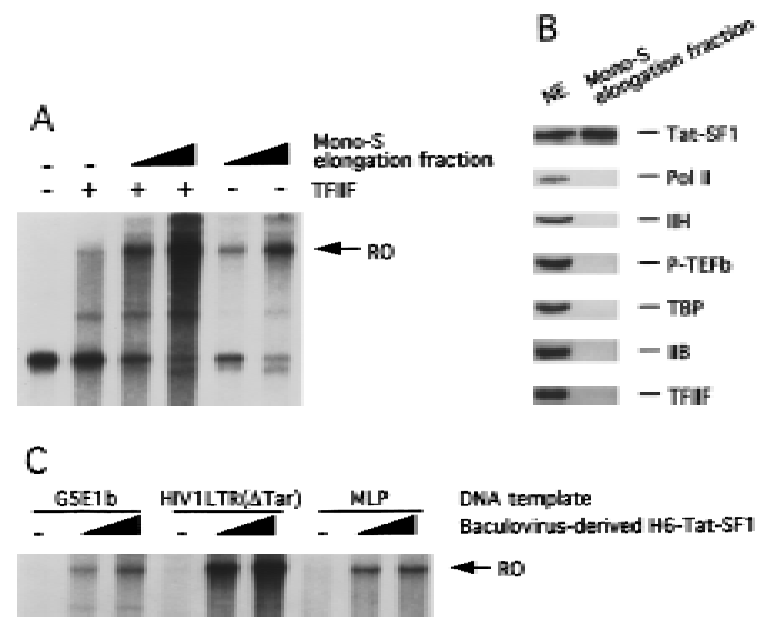

Figure 3. Tat-SF1 is a general transcription el ongation factor. (A) The elongation activity present in the $0.5 \mathrm{~m}$ Tat-affinity column eluate was partially purified as described in $M$ aterials and $M$ ethods. Peak fraction containing this factor from the final Mono S column $(2,4 \mu \mathrm{l})$ and a TFIIF-containing fraction $(2 \mu \mathrm{l})$ were added individually or together to the Tat-affinity column FT. Run-off transcripts on the G5E1b template are shown. (B) The $\mathrm{M}$ ono $\mathrm{S}$ fraction containing the elongation activity was analyzed by immunoblotting using antibodies against the indicated factors. (C) The same as A except that baculovirus-derived Tat-SF1 was used. The DNA templates are indicated. 
clude that Tat-SF1 is a general transcription-elongation factor.

Tat-SF1 was identified originally as a Tat-specific coactivator (Zhou and Sharp 1995, 1996) and therefore its depl etion was expected to abolish Tat-directed transcription activation. To confirm this prediction, we used a previously described Tat-transactivation assay that involves an initial preincubation of the nuclear extract (or fractions thereof) with ATP (M arciniak and Sharp 1991). Figure 4A shows, as expected, that the flow through of a Tat-affinity col umn failed to support Tat-activated transcription, whereas efficient activation by Tat was observed with the crude nuclear extract input and the flow through of the Tat-mutant column. Figure 4B shows that the Tat-affinity column $0.5 \mathrm{~m}$ el uate complemented the ability of the Tat-affinity column flow through to support Tat-directed transcription activation, which as expected, was observed with the wild-type but not mutant [HIV-1LTR( $(\Delta T$ Tr)] LTR template. Figure 4C shows that addition of TFIIF to the Tat-affinity column flow

A
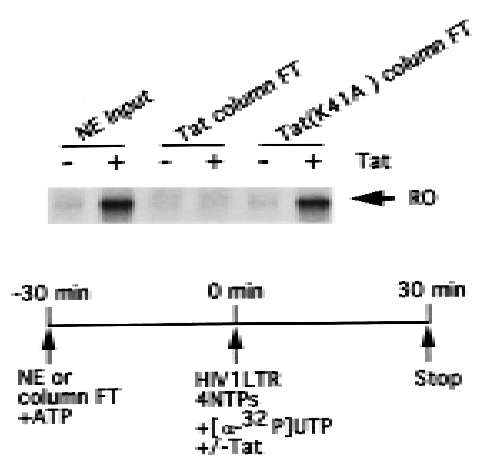

B

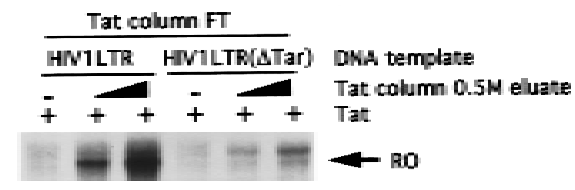

C

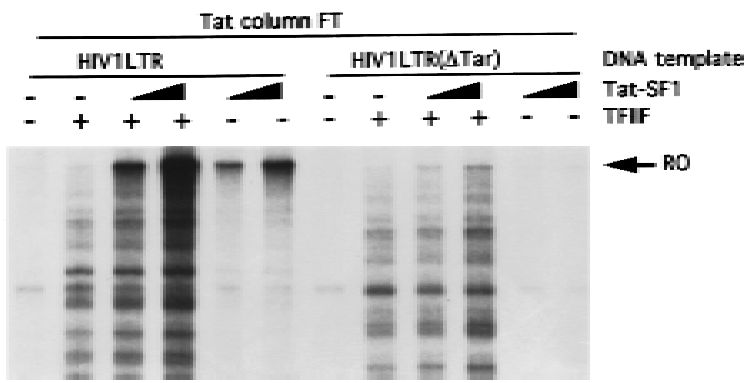

Figure 4. Tat-SF1 is required for transcription activity by $\mathrm{T}$ at. Affinity chromatography was performed as described in Fig. 1. (A) The nuclear extract input and the FT fractions from the Tat protein-affinity column and the control column were tested in a Tat-transactivation assay as shown schematically. (B) The 0.5 $\mathrm{M}$ eluate from the Tat protein-affinity column $(0,5$, or $10 \mu \mathrm{l})$ was tested for complementation of the Tat protein-affinity column FT for activation by Tat. (C) The same as B except that TFIIF (2 $\mu \mathrm{l})$ and Tat-SF1 $(2,4 \mu \mathrm{l})$ from the M ono S column were added.
A

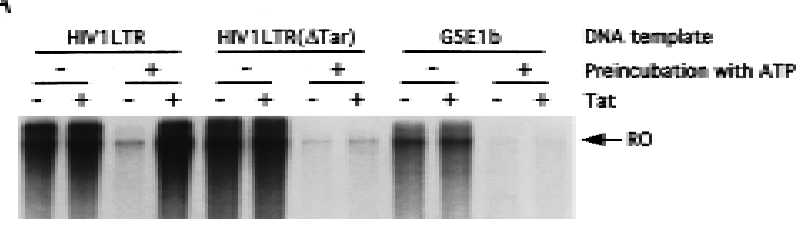

B

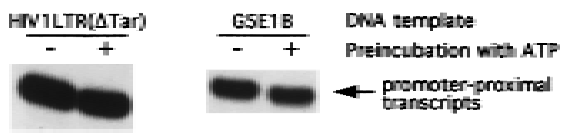

Figure 5. Preincubation of nuclear extract with ATP inactivates an elongation factor, AIEF. N uclear extract was preincubated in the presence or absence of ATP. Tat and DNA templates were added as indicated. (A) RO transcripts; (B) primerextension products.

through increased the overall production of transcripts from both the wild-type and mutant LTR templates but was not required for activation by Tat. In contrast, TatSF1 complemented the Tat-affinity column flow through to support synthesis of full-length transcripts from the HIV LTR but not HIV-1LTR( $\Delta$ Tar) DNA template (Figure $4 B, C)$. These results indi cate that Tat-SF1 is required for activation by Tat, consistent with previous studies (Zhou and Sharp 1995, 1996).

The results of Figure 3 indicate that Tat-SF1 can stimulate el ongation in the standard nuclear extract but following preincubation with ATP the ability of Tat-SF1 to simulate elongation required Tat (Fig. 4). Figure 5A shows that preincubation of the nucl ear extract reduced production of the 1600-nucleotide run-off transcript drastically without affecting initiation (Figure 5B). Therefore, the preincubation step inactivated an el ongation activity, which we refer to as ATP-inactivatable el ongation factor (AIEF). AIEF is a general el ongation factor because the effect of preincubation was observed with several different DN A templates tested. Taken together, our results suggest that general transcription elongation requires both Tat-SF1 and AIEF. Because Tat can activate transcription in an ATP-preincubated extract that lacks functional AIEF, we conclude that Tat can substitute for AIEF on the HIV LTR.

The intrinsic elongation efficiency of RNA polymerase II is relatively low and is increased by a set of elongation factors including SII, SIII (elongin), ELL and pTEFb, and transcription initiation factors TFIIF and TFIIH (for review, see Bentley 1995; Reine et al. 1996). Here we have shown that Tat-SF1 is also a general elongation factor. Further studies will be required to determine how Tat-SF1 stimulates el ongation. Because TatSF1 does not affect promoter-proximal transcription, and is required for Tat function, we speculate that it increases the processivity of the transcription complex. Tat-SF1 is a member of a family of factors that include EWS, TLS/FUS, Drosophila SARFH, and $\mathrm{hTAF}_{11} 68$, all of which share a similar RN A binding motif. Accumulating evidence suggests that these factors are involved in tran- 
scription (Bertolotti et al. 1996 and references therein). However, further studies are needed to define the relationship between these factors and determine their roles in transcription elongation.

Previous studies have shown that Tat-SF1 is essential for Tat-transactivation (Zhou and Sharp 1995, 1996), and a role for TFIIF in Tat function has also been suggested (Kato et al. 1992). Our finding that a Tat-affinity column can selectively and efficiently bind Tat-SF1, and to a lesser extent TFIIF, is consistent with these previous reports. We have shown that Tat-SF1 is required for Tat function and thus is also an essential Tat-specific coactivator as reported previously (Zhou and Sharp 1995, 1996). However, whereas the previous studies suggested that Tat-SF1 was Tat-specific, instead we find it is a general el ongation factor. This apparent discrepancy can be explained readily by considering the assays used in the different studies. The Tat-transactivation assay used in this and the previous studies (Zhou and Sharp 1995, 1996) involves preincubation of nuclear extract with ATP. We have shown that this preincubation inactivates a general elongation activity, AIEF. Because AEIF is a general elongation factor, following ATP-preincubation elongation becomes inefficient; under these conditions, efficient el ongation occurs only on the HIV LTR in the presence of $T$ at. These results indicate that $T$ at can substitute functionally for AIEF and further suggest that Tat-SF1 cooperates normally with AIEF to stimulate transcription elongation of cellular genes. AIEF could correspond to one of the previously identified elongation factors, but based upon several criteria, including its chromatographic properties, we think it is most likely a novel activity (X.-Y. Li and M.R. Green, unpubl.).

In addition to Tat-SF1, several other factors have been implicated in Tat-transactivation (Herrmann and Rice 1995; Parada and Roeder 1996; Cujec et al. 1997; GarciaMartines et al. 1997; Moncebo et al. 1997; Suñé et al. 1997; Zhu et al. 1997; Wei et al. 1998; Wu-Baer et al. 1998). Of these, TFIIH and P-TEFb have been studied most extensively (Parada and Roeder 1996; Cujec et al. 1997; Garcia-Martines et al. 1997; Moncebo et al. 1997; Zhu et al. 1997; Wei et al. 1998). Both TFIIH and P-TEFb can phosphorylate the CTD of RN A polymerase II, a process thought to be stimulated by Tat. CTD phosphoryIation is believed to be important during promoter clearance and required to counteract the effect of el ongation inhibitory factors (for review, see Jones 1997). However, CTD phosphorylation may not be sufficient for Tattransactivation: Tat-transactivation can be detected under conditions in which the CTD phosphorylation is unaffected (Keen et al. 1997). CTD phosphorylation may also be required to recruit el ongation factors to the elongation compl ex, and our results rai se the possi bility that Tat-SF1 is one such a factor. Significantly, Tat-SF1 can associate with and be phosphorylated by P-TEFb (Zhou et al. 1998).

It has been reported previously that Tat can stimulate transcription by counteracting the inhibitory effect of sodium citrate, which apparently involves TFIIH (Parada and Roeder 1996). Our work further implicates an ATP- inactivatable general el ongation factor, AIEF. Collectively, these various studies suggest that Tat functions through multiple factors. Future experiments will be required to define the precise roles of these factors in general and Tat-directed transcription elongation.

\section{Materials and methods}

Plasmids

pGEXFH-Tat and pGEXFH-Tat(K41A) contain, respectively, the DNA fragments encoding the HIV-1 Tat protein (amino acids 1-86) and its mutant, Tat(K41A), fused in-frame to the GST-Flag-HMK sequence in pGEX2T (128/129). The plasmids p(-119)HIV-1LTRCAT, p(-119)HIV1LTRCAT( $\Delta$ Tar) (Southgate and Green 1991), and pG5E1bCAT (Lillie and Green 1989) have been described previously.

Preparation of GST-Tat and GST-Tat(K41A)

The procedure was the same as described previously with modifications ( $\mathrm{Li}$ and Green 1996b). Briefly, $20 \mu \mathrm{M} \mathrm{ZnCl}$ was added to the bacterial culture prior to induction by IPTG. The cell lysate was prepared in a lysis buffer [20 mм Tris-Cl (pH 8.0), $1 \mathrm{~m} \mathrm{~N} \mathrm{aCl}, 20 \mu \mathrm{M} \mathrm{ZnCl}_{2}, 0.1 \%$ N P-40, 1 mм DTT, and protease inhibitors]. After batch incubation, glutathioneagrose beads containing bound GST-fusion proteins were transferred to a column, and washed extensively first with the lysis buffer and then with buffer B [20 mM HEPES (pH 8.0), $300 \mathrm{~mm} \mathrm{KCl}, 20 \mathrm{~mm} \mathrm{ZnCl} 2,10 \%$ glycerol, $0.1 \%$ N P-40, $0.5 \mathrm{~mm}$ DTT, and $0.5 \mathrm{~mm}$ PMSF]. The proteins were eluted with buffer $\mathrm{B}$ containing glutathione and dialyzed extensively against buffer $B$.

\begin{abstract}
Tat protein-affinity chromatography
The Tat protein-affinity column and the control column contained, respectively, GST-T at and GST-Tat(K41A) immobilized on glutathioneagarose beads at a concentration of $\sim 3 \mathrm{mg} / \mathrm{ml}$. The columns, with a volume of $1 \mathrm{ml}$ each, were washed extensively first with the lysis buffer and then with buffer $D$ [20 mM HEPES (pH 8.0), $0.2 \mathrm{~mm}$ EDTA, $0.5 \mathrm{~mm}$ DTT, and $0.5 \mathrm{~mm} \mathrm{PMSF}$ ] containing $0.1 \mathrm{M} \mathrm{KCl}$ and $20 \mu \mathrm{M} \mathrm{ZnCl}_{2}$. Nuclear extract $(3 \mathrm{ml})$ was passed through the columns at a flow rate of 1.5 column vol $/ \mathrm{hr}$. The columns were washed with buffer $\mathrm{D}$ containing 0.1 $\mathrm{M} \mathrm{KCl}$, and bound protein eluted with buffer $\mathrm{D}$ containing $0.5 \mathrm{M}$ and 1.0 $\mathrm{M} \mathrm{KCl}$. The eluted fractions were dial yzed against buffer $\mathrm{D}$ containing 0.1 $\mathrm{M} \mathrm{KCl}$.
\end{abstract}

Partial purification of Tat-binding factors

The $0.5 \mathrm{~m}$ eluate from the Tat-affinity column, derived from $150 \mathrm{ml}$ of nuclear extract, was dialyzed in buffer E (20 mM HEPES, $10 \%$ glycerol, $0.2 \mathrm{~mm}$ EDTA, $0.03 \%$ N P-40, $0.5 \mathrm{~mm}$ DTT, and $0.5 \mathrm{~mm}$ PM SF) containing $0.1 \mathrm{M} \mathrm{KCl}$. The dialyzed sample was applied to a 1-ml Resource Q col umn (Pharmacia) equilibrated in $0.1 \mathrm{M}$ buffer $\mathrm{E}$, and proteins were fractionated using $20 \mathrm{ml}$ of buffer $E$ with $0.1-0.6 \mathrm{M} \mathrm{KCl}$. The fractions from the gradient were dialyzed in $0.1 \mathrm{~m}$ buffer $\mathrm{E}$ and analyzed for transcription activity in reconstitution experiments. The active fractions were pooled and loaded onto a 1-mI M ono S col umn (Pharmacia) equilibrated in $0.1 \mathrm{M}$ buffer $\mathrm{E}$, and fractionated using $20 \mathrm{ml}$ of buffer $\mathrm{E}$ with $0.1-0.6 \mathrm{M} \mathrm{KCl}$, and dialyzed in $0.1 \mathrm{M}$ buffer $\mathrm{E}$.

Run-off transcription assays

The DNA templates including pHIV-1LTRCAT, pHIV-1LTRCAT( $\triangle T$ ar), and pG5E1bCAT were linearized with $\mathrm{H}$ pal, and consequently the fulllength run-off transcripts are $~ 1600$ nucleotides. A typical transcription reaction contained $7.5 \mu \mathrm{l}$ of nuclear extract or flow through from the Tat-affinity or control column, $0.25 \mu \mathrm{g}$ of DN A template, $600 \mu \mathrm{M}$ of ATP, GTP, and CTP, $20 \mu \mathrm{M}$ UTP, $1 \mu \mathrm{Ci}(800 \mathrm{mCi} / \mathrm{mmole})\left[\alpha^{-32}\right.$ P]UTP (N EN) in the reaction buffer ( $20 \mathrm{~mm}$ HEPES, $75 \mathrm{~mm} \mathrm{KCl}, 6 \%-13 \%$ glycerol, 20 $\mu \mathrm{M} \mathrm{ZnCl}, 0.01 \%$ N P-40, 40 ng pGEM 3, $1.0 \mathrm{~mm}$ DTT, and $0.5 \mathrm{~mm}$ PM SF). GAL4-AH was added to transcription reactions using G5E1bCAT as template. Where indicated, $50 \mathrm{ng}$ Tat or its mutant Tat(K41A), purified from Escherichia coli as a GST fusion-protein, was also added. The nuclear extract was preincubated for $30 \mathrm{~min}$ at $30^{\circ} \mathrm{C}$ in the reaction buffer in the presence or absence of $300 \mu \mathrm{m}$ ATP before transcription was started by addition of DNA template and nucleotide triphosphates including $[\alpha-$ ${ }^{32}$ PJUTP. ATP was added during preincubation in the Tat-transactivation assay but not in standard transcription assay. Transcription reactions 


\section{Li and Green}

were allowed to proceed for $30 \mathrm{~min}$. Transcripts were purified and analyzed on a $5 \%$ denaturing polyacrylamide gel containing $8 \mathrm{~m}$ urea.

Transcription initiation assay

Transcription reactions were carried out as described above without $\left[\alpha-{ }^{32}\right.$ P ]UTP. Primer-extension analysis was performed as described by Lin et al. (1988) using a primer corresponding to a sequence near the transcription start site.

Purification of H6-Tat-SF1

A DNA fragment encoding Tat-SF1 (Zhou and Sharp 1996) was cloned into the BgllI-EcoRI site of the pBlueBacHis2B vector (Invitrogen). The resulting plasmid was cotransfected with linearized Bac-N-Blue DNA into SF9 cells. Recombinant virus obtained was used to express Tat-SF1 with a His-tag at the amino terminus in SF9 cells. The cells were harvested $60 \mathrm{hr}$ postinfection, resuspended in lysis buffer $[20 \mathrm{~mm}$ Tris- $\mathrm{Cl}(\mathrm{pH}$ 8.0 ), $500 \mathrm{~mm} \mathrm{~N} \mathrm{aCl}, 0.1 \% \mathrm{NP}-40,5 \mathrm{~mm} \beta$-mercaptoethanol and protease inhibitors], and lysed by brief sonication. After it was cleared by centrifugation, the lysate was loaded onto a $\mathrm{Ni}^{2+}$-agarose column, which was then washed extensively with the lysis buffer containing $20 \mathrm{~mm}$ imidazole. H6-Tat-SF1 was eluted from the column with the lysis buffer containing $100 \mathrm{~mm}$ imidazole, and was dialyzed against buffer D containing $0.1 \mathrm{M} \mathrm{KCl}$.

\section{Acknowledgments}

We thank D. Reinberg, R. Drapkin, R.C. Conaway, J.W. Conaway, P.A. Sharp, Q. Zhou, D. Price, and M. Sawadogo for providing valuable reagents, and L. Qiang for excellent technical assistance. M.R.G. is an investigator of the Howard Hughes Medical Institute. This work was supported by a grant from the N ational Institutes of Health to M.R.G.

The publication costs of this article were defrayed in part by payment of page charges. This article must therefore be hereby marked 'advertisement' in accordance with 18 USC section 1734 solely to indicate this fact.

\section{References}

Aso, T., W.S. Lane, J.W. Conaway, and R.C. Conaway. 1995. Elongin (SIII): A multisubunit regulator of elongation by RNA polymerase II. Science 269: 1439-1443.

Bentley, D.L. 1995. Regulation of transcriptional elongation by RNA polymerase II. Curr. Opin. Genet. Dev. 5: 210-216.

Bertolotti, A., Y. Lutz, D.J. Heard, P. Chambon, and L. Tora. 1996 hTAFII68, a novel RNA/sSDNA-binding protein with homology to the pro-oncoproteins TLS/FUS and EWS is associated with both TFIID and RNA polymerase II. EMBO J. 15: 5022-5031.

Cullen, B.R. 1993. Does HIV-1 Tat induce a change in viral initation rights? Cell 73: 417-420.

Cujec, T., H. Okamoto, K. Fujinaga, J. M eyer, H. Chamberlin, D. M organ, and B. Peterlin. 1997. The HIV trans-activator Tat binds to the CDKactivating kinase (CAK) and activates the phosphorylation of the $C$ terminal domain of RNA polymerase II. Genes \& Dev. 11: 26452657.

Drapkin, R., J.T. Reardon, A. Ansari, J.-C. Huang, L. Zawel, K. A hn, A. Sancar, and D. Reinberg. 1994. Dual role of TFIIH in DNA excision repair and in transcription by RNA polymerase II. Nature 368: 769772.

Feinberg, M.B., D. Baltimore, and A.D. Frankel. 1991. The role of Tat in the human immunodeficiency virus life cycle indicates a primary effect on transcription el ongation. Proc. Natl. Acad. Sci. 88: 40454049.

Garcia-M artines, L., G. Mavankal, J. N eveu, W. Lane, D. Ivanov, and R. Gaynor. 1997. Purification of a Tat-associated kinase reveals a TFIIH complex that modulates HIV-1 transcription. EMBO J. 16: 28362850.

Garrett, K.P., T. Aso, J.N. Bradsher, S.I. Foundling, W.S. Lane, R.C. Conaway, and J.W. Conaway. 1995. Positive regulation of general transcription factor SIII by a tailed ubiquitin homolog. Proc. Natl. Acad. Sci. 92: 7172-7176.

Gold, M.O., X. Yang, C.H. Herrmann, and A.P. Rice. 1998. PITALRE, the catalytic subunit of TAK, is required for human immunodeficiency virus Tat transactivation in vivo. J. Virol. 72: 4448-4453.
Herrmann, C.H. and A.P. Rice. 1995. Lentivirus Tat proteins specifically associate with a cellular protein kinase, TAK, that hyperphosphorylates the carboxyl-terminal domain of the large subunit of RN A polymerase II: Candidate for a Tat cofactor. J. Virol. 69: 1612-1620.

Jones, K.A. 1997. Taking a new TAK on Tat transactivation. Genes \& Dev. 11: 2593-2599.

Jones, K.A. and B.M. Peterlin. 1994. Control of RNA initiation and elongation at the HIV-1 promoter. Annu. Rev. Bochem. 63: 717-743.

Kao, S.Y., A.F. Calman, P.A. Luciw, and B.M. Peterlin. 1987. Antitermination of transcription within the long terminal repeat of HIV by the tat gene product. Nature 330: 489-493.

Kato, H., H. Sumimoto, P. Pognonec, C.H. Chen, C.A. Rosen, and R.G. Roeder. 1992. HIV-1 Tat acts as a processivity factor in vitro in conjunction with cellular el ongation factor. Genes \& Dev. 6: 655-666.

Keen, N., M. Churcher, and J. Karn. 1997. Transfer of Tat and release of Tar RNA during the activation of the human immunodeficiency virus type-1 transcription el ongation complex. EMBO J. 16: 5260-5272.

Laspia, M.F., A.P. Rice, and M.B. Mathews. 1989. HIV-1 Tat protein increases transcriptional initiation and stablizes elongation. Cell 59: 283-292.

Li, X.-Y. and M.R. Green. 1996a. Transcription elongation and Cancer. Curr. Biol. 6: 943-944.

- 1996b. Intramolecular inhibition of activating transcription factor-2 function by its DNA-binding domain. Genes \& Dev. 10: 517527.

Lillie, J.W. and M.R. Green. 1989. Transcriptional activation by the adenovirus Ela protein. Nature 338: 39-44.

Lin, Y.-S., M.F. Carey, M. Ptashne, and M.R. Green. 1988. GAL4 derivatives function al one and synergistically with mammalian activators in vitro. Cell 54: 659-664.

M ancebo, H., G. Lee, J. Flygare, J. Tomassini, P. Luu, Y. Zhu, C. Blau, D. Hazuda, D. Price, and O. Flores. 1997. P-TEFb kinase is required for HIV Tat transcriptional activation in vivo and in vitro. Genes \& Dev. 11: 2633-2644.

Marciniak, R.A. and P.A. Sharp. 1991. HIV-1 Tat protein promotes formation of more processive el ongation complexes. EMBO J. 10: 41894196.

M arciniak, R.A., B.J. Calnan, A.D. Frankel, and P.A. Sharp. 1990. HIV-1 Tat protein trans-activates transcription in vitro. Cell 63: 791-802.

Parada, C. and R. Roeder. 1996. Enhanced processivity of RNA polymerase II triggered by Tat-induced phosphorylation of its carboxyl-terminal domain. Nature 384: 375-378.

Reine, D., J.W. Conaway, and R.C. Conaway. 1996. The RN A polymerase II general elongation factors. Trends Biochem. Sci. 21: 351-355.

Shilatifard, A., W.S. Lane, K.W. Jackson, R.C. Conaway, and J.W. Conaway. 1996. An RN A polymerase II elongation factor encoded by the human ELL gene. Science 271: 1873-1876.

Southgate, C.D. and M.R. Green. 1991. The HIV-1 Tat protein activates transcription from an upstream DNA-binding site: implications for Tat function. Genes \& Dev. 5: 2496-2507.

Suñé, C., T. Hayashi, Y. Liu, W.S. Lane, R.A. Young, and M.A. GarciaBlanco. 1997. CA150, a nuclear protein associated with the RNA polymerase II holoenzyme, is involved in Tat-activated human immunodeficiency virus type 1 transcription. Mol. Cell. Biol. 17: 60296039.

Wei, P., M.E. Garber, S.-M . Fang, W.H. Fischer, and K.A. Jones. 1998. A novel CDK9-associated C-type cyclin interacts directly with HIV-1 Tat and mediates its high-affinity, loop-specific binding to Tar-RN A Cell 92: 451-462.

Wu-Baer, F., W.S. Lane, and R.B. Gaynor. 1998. Role of the human homol og of the yeast transcription factor SPT 5 in HIV-1 Tat-activation. J. Mol. Biol. 277: 179-197.

Zhou, Q. and P.A. Sharp. 1995. N ovel mechanism and factor for regulation by HIV-1 Tat. EMBO J. 14: 321-328.

- - . 1996. Tat-SF1: Cofactor for stimulation of transcriptional elongation by HIV-1 Tat. Science 274: 605-610.

Zhou, Q., D. Chen, E. Pierstorff, and K. Lou. 1998. Transcription elongation factor P-TEFb mediates Tat activation of HIV-1 transcription at multiple stages. EMBO J. 17: 3681-3691.

Zhu, Y., T. Peery, J. Peng, Y. Ramanathan, N. M arshall, T. Marshall, B. Amendt, M. Mathews, and D. Price. 1997. Transcription el ongation factor P-TEFb is required for HIV-1 Tat transactivation in vitro. Genes \& Dev. 11: 2622-2632. 


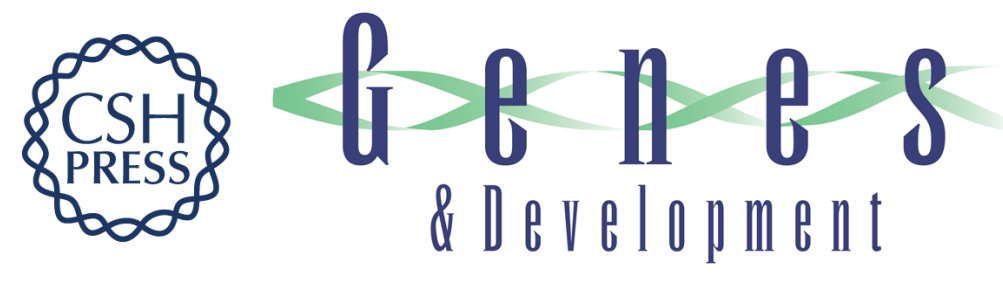

\section{The HIV-1 Tat cellular coactivator Tat-SF1 is a general transcription elongation factor}

Xiao-Yong Li and Michael R Green

Genes Dev. 1998, 12:

Access the most recent version at doi:10.1101/gad.12.19.2992

References This article cites 35 articles, 18 of which can be accessed free at: http://genesdev.cshlp.org/content/12/19/2992.full.html\#ref-list-1

License

Email Alerting

Receive free email alerts when new articles cite this article - sign up in the box at the top Service right corner of the article or click here.

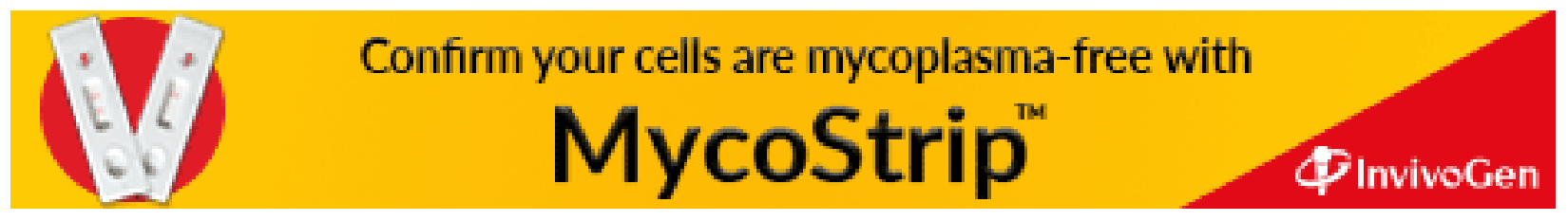

